\title{
DEMOCRACIA EM VERTIGEM
}

\author{
J.H.L. MONTEIRO', A.C. SILVA ${ }^{2}$ \\ Universidade Estadual de Maringá', Centro Universitário Ingá ${ }^{2}$ \\ Jlima_monteiro@hotmail.com ${ }^{1}$
}

Submetido 06/02/2020- Aceito 28/03/2020

DOI: $10.15628 /$ holos.2020.9514

Documentário: "Democracia em vertigem"

Data de lançamento: 19 de junho de 2019 na Netflix ( $2 \mathrm{~h} 1 \mathrm{~min}$ )

Direção: Petra Costa

Nacionalidade: Brasileiro

O documentário "Democracia em vertigem" é uma produção de 2019 realizada por Petra Costa, a qual teve seus direitos de distribuição adquiridos pela Netflix em 19 de junho de 2019. 0 filme acorre a vida da cineasta produtora de maneira íntima e pessoal, relatando fatos marcantes da política brasileira, desde o primeiro mandato do presidente Lula (2002 a 2006) até o processo de impeachment da presidente Dilma Rousseff, em 2016.

Ana Petra Costa, filha dos militantes: Manoel Costa e Marília Andrade, neta de um dos fundadores da construtora Andrade Gutierrez, relata fatos de sua vida pessoal dentro do contexto político brasileiro. Seus pais ficaram durante dez anos em Londrina, fugindo da Ditadura Militar, e, mesmo assim, tentavam organizar movimento de estudantes e trabalhadores. Petra recebeu este nome em memória a Pedro Pomar, militante morto que era mentor de seus pais.

A revolução almejada por seus pais nunca acontecera, porém, em 1979, os ventos começam a mudar, quando milhares de operários entraram em greve no Sindicato dos Metalúrgicos do ABC, desafiando a ordem da Ditadura, lideradas pelo líder sindical e metalúrgico, Luiz Inácio Lula da Silva, o Lula. Lula desperta seu interesse pela política, quando entra no congresso brasileiro e percebe que, dentre os 443 parlamentares, somente 2 eram da classe trabalhadora.

Em 1980, Lula lidera a criação do Partido dos Trabalhadores (PT). Candidata-se a presidência do Brasil em três eleições consecutivas: 1989, 1994 e em 1998, perdendo em todas. Em 2002, optando pela conciliação e não mais o debate frente ao mundo empresarial, Lula vence as eleições obtendo $61 \%$ dos votos válidos. Neste momento, emerge na população a esperança de que as desigualdades sociais seriam enfrentadas.

Então presidente, Lula enfrenta embates para obter a maioria do congresso, surgindo com o tempo o "mensalão". Aos poucos, Lula se distancia dos escândalos, o que viria a persegui-lo tempos depois.

Em seu governo, muitas mudanças ocorreram na vida da população brasileira que o fizeram ainda mais popular. Dentre tais mudanças: Cerca de 20 milhões de pessoas saíram da pobreza com o programa Bolsa Família, criado pelo Governo Federal. Triplica o número de negros nas Universidades. A taxa de desemprego tem o menor índice de sua história, e, enquanto a crise de 2008 se espalha, o Brasil passa da 13aㅡ para a 7ạ economia do mundo.

Em um encontro com o então presidente americano Barack Obama, este diz a Lula: "amo o Lula. É o político mais popular do mundo". Com o tempo, Lula fez aquilo que talvez tenha sido um de seus maiores erros políticos, realiza aliança com o partido mais poderoso do congresso, o PMDB ${ }^{1}$.

\footnotetext{
${ }^{1}$ Lula fez aliança com a velha oligarquia brasileira, a política que ele sempre criticou.
} 
Os ministros da época, Dirceu e Palocci renunciam, cotados a serem sucessores de Lula. O pré-sal, fonte de riquezas, o qual seria usado para financiar programas sociais pela estatal Petrobras, "era uma benção que logo se anunciaria como maldição".

Em 2010, ao fim de seu segundo mandato, Lula apresenta Dilma Rousseff como sua sucessora. Ex guerrilheira, Dilma foi presa aos 22 anos de idade, e, tem no documentário, uma foto sua sendo interrogada, após 22 dias de tortura, em 1970.

No dia 31 de outubro de 2010, Dilma Rousseff vence as eleições e se torna a primeira mulher presidente do Brasil. Durante o documentário, a Mãe de Petra, Marília, relata que a vitória de Dilma para a presidência representava também sua identidade, visto que Marília quando jovem também viera a ser presa no mesmo presídio de Dilma.

Lula deixa o cargo em 1 de janeiro de 2011 com 87\% de aprovação, sendo uma das maiores já alcançadas por qualquer presidente no mundo. Porém, deixa a aliança com o PMDB. "Um casamento arranjado" entre PMDB e o PT. Temer, líder do partido pmdebista e um político conservador, deveria ser o vice de Dilma. No entanto, Lula, ao ser questionado sobre a aliança, disse que "se Jesus viesse para o Brasil, teria que fazer aliança até com Judas".

Brasília, a cidade utópica de Juscelino a qual abriga o sonho da democracia, vem a ter seu abalo em junho de 2013. Protestos contra a tarifa do ônibus, associado à mídia e às redes sociais, se tornaria uma das maiores manifestações da história do Brasil. Os protestos fazem com que o apoio popular seja perdido pelo governo. Após uma década no poder, a bandeira do PT parecia não mais espelhar os desejos da população, tornando-se, nesse momento, 0 alvo.

Dilma, indo na contramão da conciliação, retira cargos do PMDB e obriga os bancos a reduzirem os juros.

A operação intitulada lava jato, investiga a Petrobras, que, anos antes, havia sido alvo de espionagem da Agência Nacional de Segurança dos Estados Unidos (EUA). Em pouco tempo, os investigadores revelam uma teia de corrupção que interliga a Petrobras, empreiteiras e os principais partidos políticos. Sérgio Moro, juiz federal do Paraná, treinado nos EUA e inspirado na operação italiana "mãos limpas", aprende a usar a mídia a seu favor e, boa parte desta, abraça sua narrativa sem nenhum questionamento. Mantendo suspeitos na cadeia sem julgamentos, a operação se converte em um thriller policial brasileiro, até que os suspeitos apresentem figuras que sejas ainda mais importantes, e eles aparecem. Nessa direção, Nestor Cerveró, ex-executivo da Petrobras, em depoimento durante a investigação da lava jato, disse que o fenômeno da corrupção está em todas as estatais e sempre existiu (como uma tradição) e não era algo exclusivo do governo Lula. Paulo Roberto Costa, ex-diretor da Petrobras explanou que é como uma areia movediça, a qual você entra e depois não consegue sair mais. Marcelo Odebrecht, ex-presidente do Grupo Odebrecht, relatou que caixa 2 nem era mais considerado como crime, devido ser algo comum. À medida que os empresários começaram a falar, políticos de vários partidos começam a ser presos, incluindo membros do Partido dos Trabalhadores. Muitos culpam Dilma por não intervir nas investigações, uma atitude que levaria a sua queda.

Para a reeleição de Dilma, em 2014, surge por principal adversário Aécio Neves, neto de expresidente e apoiado por grande parte das empreiteiras. Aécio perde as eleições para Dilma, mas por uma pequena vantagem. Não aceitando o resultado das eleições, seu partido pede apuração das urnas e inicia um processo de defesa do impeachment de Dilma nove meses após a eleição. Nesse momento, transmitido pelas mídias cada detalhe, diversos grupos políticos de direita defendem um discurso anticorrupção e transformam os atos em uma insurreição contra Dilma, Lula, consequentemente, contra o PT. Nesse contexto turbulento na política brasileira, Dilma quebra sua promessa de campanha e implementa um programa de austeridade. O desemprego chega a $8 \%$. 
Mais de 4 milhões de pessoas voltam a pobreza e a taxa de aprovação do governo cai para 9\%. Em dezembro de 2015 , os chamados "batedores de panela" comemoram a abertura do processo de impeachment de Dilma no congresso.

No dia 04 de março de 2016, suspeitando do envolvimento de Lula no esquema de corrupção, os investigadores procuram provas de que ele teria recebido um apartamento como propina de uma construtora implicada na lava jato. Mesmo sem acusação formal, um espetáculo acerca de Lula é criado e ele acaba sendo levado "a força" pela Polícia Federal a qual cria um ambiente de culpa. Doze dias depois, Lula anuncia que será o novo Ministro da Casa Civil, a convite de Dilma. Em uma ligação grampeada, Dilma diz a Lula que enviará o termo de posse para utilizá-lo somente em caso de necessidade. Ao ter esse áudio vazado, emerge duas opiniões entre a população: (a) para alguns, esse fato era para ter acesso ao foro privilegiado e, assim, escapar da prisão; (b) para outros, era prova de que Sergio Moro estava usando de seu poder de juiz para tirar Lula do jogo político. Diversas pessoas saem às ruas apoiando Sergio Moro e pedindo a prisão de Lula. O país se divide em duas partes, apoiadores e críticos.

Nessa conjuntura, Janaína Paschoal, advogada e uma das autoras do processo de impeachment de Dilma, concedeu algumas entrevistas associando a presidente as "cobras". Eduardo Cunha, presidente da Câmara dos Deputados no período, abre o processo de impeachment, montando a estrutura do golpe. Seiscentos (600) parlamentares decidiriam o futuro do Brasil. Cria-se uma comissão que se torna o primeiro passo, pois depois passaria para uma votação no plenário da câmara e, por fim, no senado, como juízo final. De um lado, uns diziam que Dilma era a culpada por tudo de ruim que acarretava o país, de outro, diziam que a acusação contra ela não justificava o impeachment.

Alguns parlamentares falavam que Dilma foi incompetente, outros afirmavam que sua relação contrária a conciliação que a fez "cutucar a onça com vara curta". A elite foi atingida aos dizeres que pagaria pela crise.

Em 17 de abril de 2016, acontece a votação do impeachment na câmara dos deputados. O documentário mostra, na época, o deputado Jair Messias Bolsonaro, fazendo sinais de "roubo" durante o processo de votação. Bolsonaro acabara de se lançar candidato à presidência. Capitão reformado, dizia-se contra o comunismo e exaltava em seus discursos o torturador mais infame da ditadura brasileira, em memória do Coronel Carlos Alberto Brilhante Ustra, considerado por Bolsonaro o "pavor de Dilma Rousseff".

Depois da votação na câmara, o senado suspende Dilma por 112 dias, até seu julgamento final. Em 12 de Maio de 2016, sai a primeira presidente mulher e assume Temer interinamente, com um ministério somente de homens, todos brancos. Nesse contexto, as bancadas do boi, da bala, da bíblia e a extrema direita ganham forças no congresso.

Petra, em um de seus momentos íntimos de gravação com sua família, interroga sua mãe, Marília, sobre os escândalos de corrupção. Marília disse que aquilo não a espantava, o que a espantava era a lava jato fazer com que políticos e empresários fossem presos e interrogados. Porém, para ela, isso não foi imparcial, foi partidarizado. Aparentemente, a estrutura da elite do Estado objetivava eliminar a ameaça da esquerda (tirar o Lula, derrubar a Dilma, acabar com o PT), nem que para isso fosse necessário eliminar uma parte da elite, que eram os empreiteiros.

Gilberto Carvalho, ex-secretário geral da presidência do PT, relata que o partido, em seu início, era contrário à toda a forma corrompida de fazer política. Na medida em que foi crescendo e lidando com o poder, ficou no meio de uma situação em que, por um lado, ficava envolvido com as questões sociais que eram difíceis de exercer dentro do Capitalismo, as quais só se conquistam direitos com base na luta, e, por outro lado, dentro da instituição, tenta mudar a realidade desta. 
Na medida que cresceu, o foco ficou na mobilidade dentro do congresso e não em uma reforma política.

Onze dias após Temer assumir o governo, vaza um áudio gravado semanas antes da primeira votação do impeachment, no qual o ministro do planejamento de Temer, Senador Romero Jucá, é flagrado discutindo a operação lava jato com o ex presidente da TRANSPETRO. No áudio, é discutido que a melhor opção para suas motivações pessoais, ou seja, acabar com as investigações contra vossas pessoas, era colocar o Michel Temer por meio de uma decisão política, retirando dessa forma Dilma da presidência.

Reportagens internacionais discutem se o processo de impeachment da presidente era para o bem do país, visto que mais da metade dos congressistas estavam sendo investigados por crimes de corrupção, fraude, escravidão e até homicídio.

Em 29 de agosto de 2016, acontece o julgamento final do impeachment no senado. Após o impeachment aprovado, todos os olhos se voltam para a próxima eleição presidencial e Lula declara que será novamente candidato a presidente.

Duas semanas depois do impeachment, Procuradores da República da Operação Lava jato, como Deltan Dallagnol, apresentam, em Power point transmitido ao vivo pela TV, que como presidente, Lula tinha o poder de tomar decisões e estava próximo de diversas pessoas condenadas na lava jato, mas a acusação de fato, era de que após dois anos de investigação, Lula havia recebido um triplex de uma empreiteira. Em próprio discurso do procurador, alega e relata que "não teremos aqui provas cabais de que Lula é efetivo proprietário no papel do apartamento".

O documentário mostra que a esposa de Lula, Marisa Letícia Lula da Silva, também foi alvo das investigações. Quatro (4) meses depois, ela sofre um derrame e morre.

Após depoimentos, realizados em Curitiba, de Lula frente ao juiz Sergio Moro, Lula é condenado a 9 anos e 6 meses de prisão. Seu processo chega em segunda instância mais rápido do que qualquer outro da lava jato e sua pena é aumentada para 12 anos.

Gravações do atual presidente pós golpe, Michel Temer e de Aécio Neves com o empresário dono da empresa JBS, Joesley Batista, constatam a relação de propina entre as partes. Detalhe importante: na relação do pagamento entre Aécio Neves e Joesley Batista, Aécio acerta um terceiro para intermediar o recebimento com Joesley e alega que este terceiro é uma pessoa que pode "matar antes dele fazer uma possível delação". Mesmo com a gravação, graças ao foro privilegiado e uma ajuda de seus amigos senadores, Aécio preserva seu mandato e sua liberdade.

Em 2 de agosto de 2017, acontece na câmara uma votação de denúncia contra Temer. O discurso muda. Parlamentares alegam que não faz bem ao país destituir um presidente e o caso é arquivado. Dizem que essa votação custou 4 bilhões em emendas para os deputados protegerem o presidente. $O$ fato de $80 \%$ da população apoiar a investigação de Temer não influenciou a votação do congresso nem da bolsa de valores. Enquanto isso, Temer leiloou as reservas de petróleo para as empresas estrangeiras, enfraqueceu as leis que impediam o trabalho escravo, e aprovou medidas de austeridade que prejudicava ainda mais os pobres. É normal discordar, mas aparentemente, um lado da disputa tem o poder de ligar e desligar, de acordo com seus interesses.

Seis meses antes das eleições de 2018, Lula lidera com 31\% das intenções de voto, seguido por Bolsonaro com 15\%. Bolsonaro diz que "quem garante a democracia é a vontade das forças armadas". Apesar das declarações antidemocráticas de Bolsonaro, uma parte significativa da elite começa a vê-lo como melhor alternativa para defender os interesses do mercado. No dia 4 de abril, os integrantes do Supremo Tribunal reúnem-se para decidirem se Lula pode continuar em liberdade até esgotar todos seus recursos. Por 6 votos a 5, o pedido de Lula é negado e Moro emite uma ordem que Lula se entregue a polícia em 24 horas. 
Lula alega que, em sua opinião, não faria sentido a elite da direita o deixar solto, visto que o impeachment da Dilma aconteceu para retirá-los do poder, e, solto, Lula retornaria à presidência. Seis meses após Lula ser preso, Bolsonaro é eleito presidente do Brasil. Após eleito, o juiz Sergio Moro é nomeado ministro da Justiça de Bolsonaro e Lula permanece preso, até então.

Por fim, "Democracia em vertigem" é um documentário necessário para refletir sobre o jogo político que cerca o território brasileiro. O documentário revela que durante toda sua história, o Brasil foi permeado por corrupção e desigualdades. Pensar em democracia, atualmente, parece cada vez mais utópico. 